\title{
The Influence of the Store Atmosphere on the Consumer Behavior
}

\author{
El-Bachir Sabrina \\ University of Mascara \\ Email: sabrina.elbachir@gmail.com
}

\section{Doi:10.5901/mjss.2014.v5n8p229}

\begin{abstract}
The aim of this paper is to put in evidence the influence of store atmospherics components on behavior replies (time of presence in the sales outlet, number of purchases articles, upward of buying articles), and emotional replies of consumers. From an empirical study managed next to 110 clients of the department store U.N.O, we can confirm the impact of environmental characteristics of the store (ambient elements, design) on the actions of the subject and his feelings.
\end{abstract}

Keywords: Atmosphere's sales outlet, consumer behavior, emotional responses, design, ambient factors

\section{Introduction}

The influence of the environment on behavior has long been acknowledged by retailers, architects and interior designers (Baker and al., 1992; Tai and Feng, 1997; Gilboa and Rafaeli, 2003). Store atmospherics is formed by different components frequently called « atmosphere factors » such as music, smell, and colors. The dealers have to act on it to modify the behavior of the consumer (Kotler, 1974; Lemoine, 1997; Daucé et Rieunier, 2002; Rieunier et al, 2002). According to Bitner (1992): "There is a surprising lack of empirical research and theoretically based frameworks addressing the role of physical surroundings in consumption settings ". In more recent times Spangenberg et al (2005) point out that "although environmental stimuli have been found to influence shopping behavior, empirical knowledge of how these variables interact to affect shopper perceptions and actions is lacking".

In 1974, Kotler said that the atmosphere of a store cause several reactions on the consumer. It can influence his conative replies (upgrade his purchase, expenditures, impulse buying, the desire to spend more time in the shop), it can also have an impact on his affective replies (pleasure, mood, emotion) and cognitive (perceived quality of the service and the value of trade name). Kotler (1974) proposed that "atmospherics" were a potentially important source of competitive advantage in the retail environment. Bitner (1992) coined the term "servicescapes" in reference to the physical surroundings fashioned by retailers to facilitate the service offering to consumers. It is known that the service environment is made up of both tangible (buildings and furniture) and intangible (temperature, color, scent and music) elements which make up the service experience (Hoffman and Turley, 2002).

The majority of researches try to dismantle the influence on a unique atmospheric key. On this work, we are interested in three atmospherics factors: music, smell, and store design. Whether, three of the five senses of the "Sensory Marketing".

After an introduction to our conceptual framework and our hypothesis (looking to their validity), we expose our widely adopted methodology. At last, our results are shown.

\section{Objective and Theoretical Framework of the Research}

The aim of this research was to test the influence of the atmospherics store components on behavior and emotional replies of the consumer. The first definitions of the atmosphere are relatively poor insofar as they considered it only like an element of the store image, in the same way of path's width, lighting or the crowd (Siberil, 1994). Afterwards, this variable was conceptualized as a simple attribute which describe the perceived quality of the environment (good, pleasant, attractive, bad, etc.) (Lemoine, 2001). Now, everything seem to prove that the atmosphere can't be limited to only one characteristic, but refer to a complex mix of environmental features.

Kotler (1973), defined atmospherics as "the effort to design buying environments to produce specific emotional effects in the buyer that enhance his purchase probability" is suggesting that one of the most significant features of the product is the place where it is bought or consumed. In some cases, the place, more specifically the atmosphere of the 
place, is more influential than the product itself in the purchase decision. Given that the atmosphere is an unverifiable factor, atmospherics store can contribute on the satisfaction or the dissatisfaction of the client by affecting his perceptions. Indeed, it can influence the buyer's behavior to favor positives reactions, inciting them to adopt an approach behavior related to the environment.

According to Mehrabian and Russel (1974), and Russel (1980), the environmental stimuli have a direct effect on the approach and avoidance behaviors of participants in that environment marked by three dimensions: Pleasure, Arousal, and Dominance. The Mehrabian and Russell (1974) model is based on the Stimulus-Organism-Response (S-O$\mathrm{R})$ paradigm. The $(\mathrm{S})$ component is the environmental stimulus; the $(\mathrm{O})$ component is the emotional states and the $(\mathrm{R})$ component is the approach-avoidance responses. The (S) component identifies that specific stimuli are said to affect the emotional states of pleasure and arousal, the $(0)$ component, which is turn affects the $(R)$ component, the approachavoidance behaviors (Aubert-Gamet, 1996).

The three dimensions will influence consumer reactions that can be sum up in behavior approach: staying inside the store or escaping (leaving the shop). Indeed, a negative atmospheric store may engender an avoidance behavior or increase dissatisfaction's feeling on the costumer. While, a pleasant perception of the atmosphere create an approach behavior (Mehrabian and Russel, 1974). Sometimes, this can translate a rising of the impulse buying (Jarrier, 2006).

In order to show different manners of the atmosphere that influence consumer behavior, we proposed hypotheses:

- $\quad \mathbf{H} 1$ : The atmospherics store perception can influence the costumer on :

- $\quad$ The pleasure feeling inside the store ( $\mathrm{H} 1 \mathrm{a})$

- The stimulation feeling inside the store $(\mathrm{H} 1 \mathrm{~b})$

- $\quad \mathbf{H 2}$ : The atmospherics store perception can influence the costumer on :

- $\quad$ Time of presence in the sales outlet $(\mathrm{H} 2 \mathrm{a})$

- Number of purchasing articles (H2b)

- $\quad$ The desire in coming back to the store $(\mathrm{H} 2 \mathrm{c})$.

- The intention of future purchases $(\mathrm{H} 2 \mathrm{~d})$.

\section{Methodology of the Research}

\subsection{Place's choice of the investigation and sample size}

Our research takes place in UNO (An Algerian supermarket). The objective was to collect customers' evaluations of U.N.O through a questionnaire. Mothers's population is formed by the whole visitors of the store. The questionnaire was administered next to a sample of 110 persons.

This questionnaire is built around three axes: emotional reactions, cognitive reactions, and behavior replies. The customers wan interrogated on a face-to-face way, at the time where they were leaving the store. With this process, we insure the fact that they spend enough time inside the shop, in order to give their opinions on the physical environment of the store. We tended to interview persons that were alone; because they are more disposable to answer cautiously (no one is waiting for them). Our investigation's length were from $4 \mathrm{p} . \mathrm{m}$ to 10p.m. Otherwise, part of the day that known the most high degree of visitor.

\section{Research Dimensions and Variables}

\subsection{Atmospherics factors}

All the questions related to sensorial stimuli such as music, colors, smell are liable to Likert scales of seven points to increase noticed variance and the precision of the answers.

\subsection{Evaluation of the store atmosphere}

To evaluate the perception of the store atmosphere, we used the same items used by Spangenberg (1996).

- Not Attractive / Attractive

- Depressing/ Cheerful

- Negative / Positive

- Annoying/ Stimulated 
- Bad/Good

- Not Motivating / Motivating

○ Unpleasant/Pleasant

\subsection{Behavior states}

On this research, we were interested on, Presence time inside the shop, Number of purchasing articles, the desire in coming back to the store with a purchase intention

\subsection{Emotional states of the subject}

Neuro-scientists state affect covers both the emotions and feelings a person has toward an object or activity (Wiles and Cornwell, 1990).. Terms of our investigations (passing the questionnaire outside the store, lower availability, limited time) let us limit our investigation on the verbal techniques. According to Lemoine (2001), this kind of techniques is characterized by a high adaptability with our emotional replies, a low data collect and the absence of sophisticated tools. This dimension contains two emotional states (PA Scale (Pleasure-Arousal) from Mehrabian and Russel Model):

○ Pleasure's dimension

- Arousal's dimension

\section{Results}

\subsection{Atmospherics store's perception and the behavior of the consumer}

To test the different components of the store environment on the consumer behavior, analysis variance were leaded (ANOVA). The dependent variables are metric and store's atmosphere is measured with a semantic differential, these have been assimilated to dummy variables toward the consolidated modalities. For example, the variable which treat store arranging with a scale of seven points is transformed into a binary variable (pretty well ordered/pretty bad ordered).

We haven't obtained significant statistical results with five variables of the atmosphere of our research. On that, we can partially validate the hypotheses $\mathrm{H} 2 \mathrm{a}$, which accord that the perception of the atmospherics store influence the presence time of the consumer inside the store. However, following a lot of authors (Aremi and Kim, 1993; Siberil, 1994; Caldwell \& Hibert, 1999), we can say that our investigation confirm the impact of the environment on the number of purchasing articles. This result can be explained by the easiness access to the product on shelves, and also, the good organization of the products. Hypotheses $\mathrm{H} 2 \mathrm{~b}$ can be validated.

\begin{tabular}{|c|c|c|c|c|}
\hline Variables & $\begin{array}{l}\text { Time of presence in } \\
\text { the sales outlet } \\
\text { (mn)/Test } \mathrm{f} / \text { probability }\end{array}$ & $\begin{array}{l}\text { Number of } \\
\text { purchasing articles } \\
\text { /Test f/ probability }\end{array}$ & $\begin{array}{l}\text { The desire in } \\
\text { coming back to the } \\
\text { store/test f/ } \\
\text { probability }\end{array}$ & $\begin{array}{c}\text { The intention of } \\
\text { future purchases/test } \\
\text { f/probability }\end{array}$ \\
\hline \multicolumn{5}{|c|}{ Design } \\
\hline $\begin{array}{l}\text { Store's arrangement (pretty } \\
\text { bad/pretty well ordered) }\end{array}$ & $F=2,976 / p=0,035$ & $F=7,03 / p=0,008$ & n.s & $F=5,316 / p=0,002$ \\
\hline $\begin{array}{l}\text { Access to the products (pretty } \\
\text { difficult/pretty easy) }\end{array}$ & n.s & $F=3,057 / p=0,01$ & n.s & $F=4,796 / p=0,004$ \\
\hline $\begin{array}{l}\text { Displacement through color code } \\
\text { of departments (pretty } \\
\text { comfortable/pretty } \\
\text { uncomfortable) }\end{array}$ & n.s & $F=4,842 / p=0,10$ & n.s & $F=2,003 / p=0,118$ \\
\hline $\begin{array}{l}\text { Brightness of the store (pretty } \\
\text { bad lighted/pretty good lighted) }\end{array}$ & n.s & n.s & $F=3,267 / p=0,014$ & $\mathrm{~F}=3,235 / \mathrm{p}=0,017$ \\
\hline \multicolumn{5}{|c|}{ Ambient factors } \\
\hline $\begin{array}{l}\text { The choice of music (pretty } \\
\text { bad/pretty good chosen) }\end{array}$ & $F=4,636 / p=0,001$ & $F=3,308 / p=0,008$ & $F=5,309 / n=0,001$ & $F=3,901 / p=0,012$ \\
\hline $\begin{array}{l}\text { The volume of background music } \\
\text { (pretty low/pretty loud) }\end{array}$ & $F=2,733 / p=0,038$ & $F=2,554 / p=0,049$ & $F=4,138 / p=0,004$ & $F=2,506 / p=0,052$ \\
\hline $\begin{array}{l}\text { The effect of music while waiting } \\
\text { to pay (Pleasant/unpleasant) }\end{array}$ & $F=5,786 / p=0,001$ & n.s & $F=2,785 / p=0,032$ & n.s \\
\hline
\end{tabular}




\begin{tabular}{|l|c|c|c|c|}
\hline $\begin{array}{l}\text { The smell of the store (pretty } \\
\text { pleasent/pretty unpleasent) }\end{array}$ & n.s & $\mathrm{F}=2,548 / \mathrm{P}=0,035$ & $\mathrm{n} . \mathrm{s}$ & $\mathrm{F}=0,835 / \mathrm{p}=0,529$ \\
\hline $\begin{array}{l}\text { Purchasing through the smell } \\
\text { (tend to agree/tend to disagree) }\end{array}$ & $\mathrm{F}=5,168 / \mathrm{p}=0,001$ & $\mathrm{~F}=3,37 / \mathrm{p}=0,05$ & $\mathrm{n} . \mathrm{s}$ & $\mathrm{F}=2,982 / \mathrm{p}=0,012$ \\
\hline $\begin{array}{l}\text { Bothered by the smell (tend to } \\
\text { agree/tend to disagree) }\end{array}$ & $\mathrm{n} . \mathrm{s}$ & $\mathrm{F}=2,066 / \mathrm{p}=0,07$ & $\mathrm{n} . \mathrm{s}$ & $\mathrm{F}=1,776 / \mathrm{p}=0,159$ \\
\hline
\end{tabular}

At last, our results show that the hypotheses $\mathrm{H} 2 \mathrm{C}$ is rejected, there is no existence of any link between store atmospherics and the desire to come back to the store, or purchase intention. In conclusion, we can carefully say that:

- Hypotheses $\mathrm{H} 2 \mathrm{a}$ which stipulates that the perception collection of the store atmosphere by the consumer influences its time of presence, might partially be validated.

- Hypotheses $\mathrm{H} 2 \mathrm{~b}$ specifies that the perception of the store atmosphere by the consumer influences the number of purchasing products, is confirmed.

\subsection{The perception of store atmospherics and emotional reactions of the consumer}

Other analysis of variance was done. This analysis will make the relation between five booked items of The PA Scale (Meharbian and Russel) with the atmospheric variables.

\begin{tabular}{|c|c|c|c|c|c|}
\hline Variables & Unhappy/Happy & Melancholic/Contended & Frenzied/Sluggish & Excited/Calm & Impatient/Serene \\
\hline \multicolumn{6}{|c|}{ Design } \\
\hline $\begin{array}{l}\text { Store's arrangement (pretty } \\
\text { bad/pretty well ordered) }\end{array}$ & n.s & $F=4,091 / p=0,002$ & n.s & n.s & n.s \\
\hline $\begin{array}{l}\text { Access to the products (pretty } \\
\text { difficult/pretty easy) }\end{array}$ & $F=4,246 / p=0,001$ & $F=4,361 / p=0,001$ & $\mathrm{~F}=2,940 / \mathrm{p}=0,025$ & $F=2,536 / p=0,032$ & n.s \\
\hline \begin{tabular}{|l|} 
Displacement through color code \\
of departments (pretty \\
comfortable/pretty uncomfortable)
\end{tabular} & $F=4,027 / p=0,002$ & n.s & $\mathrm{F}=0,526 / \mathrm{p}=0,783$ & $F=4,660 / p=0,001$ & $F=3,889 / p=0,002$ \\
\hline $\begin{array}{l}\text { Brightness of the store (pretty bad } \\
\text { lighted/pretty good lighted) }\end{array}$ & $F=2,776 / p=0,015$ & $F=3,069 / p=0,013$ & $F=1,462 / p=0,222$ & $F=2,953 / p=0,015$ & n.s \\
\hline \multicolumn{6}{|c|}{ Ambient factors } \\
\hline $\begin{array}{l}\text { The choice of music (pretty } \\
\text { bad/pretty good chosen) }\end{array}$ & $F=3,117 / p=0,013$ & $F=2,615 / p=0,031$ & $\mathrm{~F}=1,673 / \mathrm{n}=0,147$ & $F=3,798 / p=0,007$ & $F=3,350 / / p=0,013$ \\
\hline $\begin{array}{l}\text { The volume of background music } \\
\text { (pretty low/pretty loud) }\end{array}$ & n.s & $F=2,554 / p=0,049$ & n.s & n.s & n.s \\
\hline $\begin{array}{l}\text { The effect of music while waiting } \\
\text { to pay (Pleasant/unpleasant) }\end{array}$ & n.s & $F=3,687 / p=0,005$ & $F=5,551 / p=0,001$ & n.s & $F=2,605 / p=0,041$ \\
\hline $\begin{array}{l}\text { The smell of the store (pretty } \\
\text { pleasent/pretty unpleasent) }\end{array}$ & $F=3,488 / p=0,004$ & $F=2,440 / P=0,042$ & n.s & n.s & n.s \\
\hline $\begin{array}{l}\text { Purchasing through the smell } \\
\text { (tend to agree/tend to disagree) }\end{array}$ & $\mathrm{F}=2,591 / \mathrm{p}=0,022$ & $F=4,333 / p=0,001$ & n.s & $F=2,729 / p=0,023$ & $F=3,272 / p=0,008$ \\
\hline $\begin{array}{l}\text { Bothered by the smell ((tend to } \\
\text { agree/tend to disagree) }\end{array}$ & $F=2,783 / p=0,021$ & n.s & $F=2,080 / p=0,110$ & n.s & n.s \\
\hline
\end{tabular}

According to previous researches treating the impact of atmospherics components on emotional replies of the consumer (For example : Gorn, Goldberg and Basu, 1993; Leenders, Smidts and Langeveld, 1999; Plichon, 1999; Siberil, 1994), we testify the positive influence that exert the atmospheric factors (background music, lighting, store's arranging, store's smell) on the degree of pleasure feeling, and his stimulation's level.

For example, a consumer who have good opinion of music and lighting, declare himself as happy, more relaxed, more cheerful, at the time of his visit comparing to the one who evaluate negatively the two atmospherics dimensions. This is how it's possible for us to assert that the atmospheric environment have a positive impact on : cheerfulness degree and good mood, pleasure level, peaceful statement. Even if the significant statistics results are numerous, they aren't systematic because of the important number of appointee's variables. Our data allow us to partially confirm H1a and $\mathrm{H} 1 \mathrm{~b}$, the perception of atmospheric store by the customer influence his pleasure and stimulation inside the store. 


\subsection{The perception of atmospherics store and emotional reactions of the consumer}

This last analysis variance has for objective to make a dependency link between the emotional feelings of the subject during his visit enterprising actions. With our result, it seem like a strong pleasure feeling inside the store related to a presence time and expended amount more important. Even if we don't obtain significant statistic results with all concerned variables, our data allow us to confirm the pleasure of the consumer inside the store and the influence of it on spending time on the store and number of purchasing articles.

\begin{tabular}{|c|c|c|c|c|}
\hline Emotional Variables & $\begin{array}{l}\text { Time of presence in the } \\
\text { sales outlet (mn)/Test } \mathrm{f} \\
\text { probability }\end{array}$ & $\begin{array}{c}\text { Number of purchasing } \\
\text { articles /Test } f / \\
\text { probability }\end{array}$ & $\begin{array}{c}\text { The desire in coming } \\
\text { back to the store/test } \mathrm{f} / \\
\text { probability }\end{array}$ & $\begin{array}{c}\text { The intention of future } \\
\text { purchases/test } \\
\text { f/probability }\end{array}$ \\
\hline \multicolumn{5}{|c|}{ Pleasure } \\
\hline Unhappy/Happy & n.s & n.s & n.s & $\mathrm{F}=2,959 / \mathrm{p}=0,011$ \\
\hline \begin{tabular}{|l|} 
Melancholic/Contended \\
\end{tabular} & $\mathrm{F}=3,94 / \mathrm{p}=0,045$ & $F=3,808 / p=0,03$ & n.s & $\mathrm{F}=3,302 / \mathrm{p}=0,010$ \\
\hline \multicolumn{5}{|c|}{ Arousal } \\
\hline \begin{tabular}{|l} 
Frenzied/Sluggish \\
\end{tabular} & n.s & $F=4,039 / p=0,003$ & $F=4,721 / n=0,001$ & $\mathrm{~F}=4,661 / \mathrm{p}=0,002$ \\
\hline Excited/Calm & n.s & n.s & n.s & $\mathrm{F}=3,695 / \mathrm{p}=0,004$ \\
\hline Impatient/Serene & n.s & n.s & n.s & $F=3,555 / p=0,006$ \\
\hline
\end{tabular}

The question to come up concern the way in which it agree to act on the persons in order to orient the behavior of the most of them. By the way, the method that consist in stimulate the subject at the time of his visit appear like a difficult and potentially dangerous exercise if it don't take place on numerous reflections as for operating manner.

The results in the table below show that the evaluation of the atmosphere of the store is significant in relation to consumer behavior. Particularly on the attraction, motivation and positive / negative atmosphere that may arise in the individual. So, if the store is considered attractive and rewarding, the consumer will tend to spend more time inside it, as well as to buy more products. It also affects the intention to return there. The hypothesis $\mathrm{H} 2 \mathrm{a}, \mathrm{H} 2 \mathrm{~b}$ and $\mathrm{H} 2 \mathrm{C}$ are confirmed.

\begin{tabular}{|c|c|c|c|c|}
\hline $\begin{array}{l}\text { Evaluation of the store's } \\
\text { atmosphere }\end{array}$ & $\begin{array}{c}\text { Time of presence in the } \\
\text { sales outlet }(m n) / T e s t ~ \\
f l \\
\text { probability }\end{array}$ & $\begin{array}{c}\text { Number of purchasing } \\
\text { articles /Test } \mathrm{fl} \\
\text { probability } \\
\end{array}$ & $\begin{array}{c}\text { The desire in coming } \\
\text { back to the store/test } \mathrm{fl} \\
\text { probability }\end{array}$ & $\begin{array}{l}\text { The intention of future } \\
\text { purchases/test } \\
\text { f/probability }\end{array}$ \\
\hline Not Attractive / Attractive & $\mathrm{F}=4,430 / \mathrm{p}=0,001$ & $F=4,257 / p=0,002$ & $\mathrm{~F}=4,410 / \mathrm{p}=0,001$ & $F=3,655 / p=0,005$ \\
\hline Depressing/ Cheerful & $F=2,052 / p=0,093$ & n.s & n.s & n.s \\
\hline Negative/Positive & $F=3,475 / p=0,010$ & n.s & $F=3,949 / p=0,005$ & $F=4,765 / p=0,001$ \\
\hline Annoying/ Stimulated & n.s & $F=4,187 / p=0,004$ & n.s & $F=5,568 / p=0,001$ \\
\hline Bad/Good & $F=3,097 / p=0,012$ & $F=4,054 / p=0,002$ & n.s & n.s \\
\hline $\mid$ Not motivating/Motivating & $F=4,049 / p=0,004$ & n.s & $F=5,451 / p=0,001$ & n.s \\
\hline Unpleasant/Pleasant & n.s & n.s & n.s & n.s \\
\hline
\end{tabular}

\section{Discussed Results}

Conclusions on our investigation present interests on theoretical and even managerial scheme. Regarding the conceptual supply of this research, we have to precise that it distinguishes itself of the anterior researches on the same domain by a global approach of atmospherics store, in view of introducing three senses (Visual, Auditory, Olfactory).

Even if we don't deny the usefulness and the great pertinence of anterior researches which focused on one specific characteristic of the atmosphere, we suppose that its desirable to integrate, on one same work, various factors are able to constitute physical and social environment of the store. On this process, it's possible for us to show in a better way the behavior of a polysensoriel consumer. His principals characteristics is to evaluate, simultaneously, commercials environments under an angle of tactile, resonant, gustatory, olfactory, visual dimensions (Divars and Urien, 2001). Otherwise, the study of the influence on different atmospherics components on behavior and emotion of the subject can facilitate managers work, with the development of a specific atmosphere on the store, wondering on an ideal manner to combine environments factors.

Managerial supplies of the present research are expressed on the acknowledgment the store environments have to be considered by dealers, retailers, traders...etc. As a management tool, able to affect positively the emotions of their clients, the number of their purchases, amount of their purchases. 


\section{Limits of Our Research}

From a theoretical point of view, we postulate that store atmosphere is limited to its physical occupied space. But, Berman and Evans (1995) shows that the atmosphere can also be composed by exteriors elements. Our study take place in a shopping centre: consumers perceived the atmosphere of the centre before they perceive atmosphere of the store. We can say that U.N.O's atmosphere is only a component of the global one. For this reason, consumer's replies are affected by the center's atmosphere, and also others shops atmosphere.

Perception measured with a scale; raise the reliability of the collected declaratives data. Privileging different facets of the environment, an experimental field, were hard to make given the large number of variables on our research.

Finally, at the level of our questionnaire, a certain number of problems was found during the administration of it : we used semantic differential scales which were badly dreaded by the consumers. Often, they believed that they had to give a mark for every quoted adjective. It had been more careful to use scales of Likert for these items, because even if the collected information is less good from a statistical point of view, it's still well adapted to the face-to-face questionnaire.

\section{Conclusion}

The aim of this research was to focus on the influence of different atmosphere factors of a store, on consumer behavior. At the end of our investigation, we can confirm the impact which three factors of environment exercise on the behavioral and emotional answers of the subject during his visit on the store. Besides, the influence of the emotional states, felt inside the store, on the actions undertaken by the customers was also verified.

In spite of the operational interests given by these conclusions, it seems careful to minimize their significance considering the inherent limits to our investigation. First of all, it should be reminded that we worked on a convenience sampling, actually reducing, the external validity of our study. This way, our research fits into an exploratory initiative which it would be advisable to complete by the realization of additional researches concerning other stores and ambient factors.

\section{References}

Ben Lallouna Hafsia Hajeret et al (2008), "L'influence des facteurs d'ambiance sur le comportement du consommateur : musique ou silence ?" Application au secteur des télécommunications, La Revue des Sciences de Gestion, n² 234, p. 97-105.

Bitner (1992), " Servicescapes: The impact of physical Surroundings on customers and employees ", JM, Vol.56.

Bloch (1995), " Seeking the ideal form: product design and consumer response ", Journal of Marketing, 59, July, 16-29.

Chebat \& Michon (2003), "Impact of ambient odors on mall shoppers'emotions, cognition, and spending ", Journal of buisness Research, $56,529-539$.

Chumpitaz \& Vanhamne (2003), " Les processus modérateurs et médiateurs : distinction conceptuelle, aspects analytiques et illustrations ", Ram, n²

Dauce \& Rieunier (2002), " Le marketing sensoriel du point de vente ", Recherche et application en Marketing, 17, 4, 45-65.

Derbaix \& Pham (1989), "Pour un développement des mesures de l'affectif en marketing : synthèse des pré requis ", Recherche et Applications en Marketing, 4, 4, 71-87.

Divard \& Urien (2001). "Le consommateur vit dans un monde en couleurs ", Recherche et Applications en Marketing, vol. 16, n¹, p. 324.

Dong-Mo \& Seon-Hee (2009), "The interactional effects of atmospherics and perceptual curiosity on emotions and online shopping intention ", Computers in Human Behavior 26 (2010) 377-388.

Eroglu, Machleit \& Chebat (2005), "The Interaction of Retail Density and Music Tempo : Effects on Shopper Responses ", Psychology and Marketing, 22, 7, 577-589.

Freyssinier, Frering, Taylor, Narendran \& Rizzo (2006), " Reducing lighting energy use in retail display windows ", Proceedings of the 6th International Conference on Solid State Lighting, SPIE (Society of Photo-optical Instrumentation Engineers), 6313.

Holland et al (1985), "Effects of Raised Body Temperature on Reasoning Memoryand Mood ", Journal of Applied Physiology, 59, 18231827.

Knez et KERS (2000), "Effects of Indoor lightninig, gender, and Age on Mood and Cognitive Performance ", Environement and Behavior, 32, 817-831.

Kotler, (1973), "Atmospherics as a Marketing Tool ", Journal of Retailing, Vol.49.

Lemoine (2001), "Comment tenir compte des émotions du consommateur ", Revue Française de Gestion, n¹34.

Lemoine (2003), "Vers une approche globale de l'atmosphère du point de vente ", Revue Française du Marketing, 194, 4/5, 83 - 101.

Lemoine (2009), "L'impact des composantes atmosphériques du point de vente sur les réactions affectives et comportementales du consommateur ", La Revue Marocaine de Recherche en Management et Marketing, Janvier 2009, №1, pp. 9-34. 
Lombart \& Labbe-Pinlon (2006), "Etude de l'impact de l'environnement du magasin sur la satisfaction du consommateur et la fidélité ", Actes des 11èmes Journées de Recherche en Marketing de Bourgogne, Dijon.

Mehrabian \& Russel, (1976), "Environmental Variables in Consumer Research. ", JCR, Vol. 3.

Mehta \& Zhu (2009), "Blue or Red? Exploring the Effects of Color on Cognitive Task Performances ", Science, vol.324, n5915, February 5th, 1226-1229.

Michon R., Chebat J.C., "The Interaction Effect of Background Music and Ambient Scent on the Perception of Service Quality", Journal of Business Research 34 (3), 191-196.

Michon R., Chebat J.C., Turley L.W (2005), "Mall atmospherics the interaction effect of the mall environment on shopping Behaviour ", Journal of Buisness Research, 58, 576-583.

Milliman (1982), "Using Background Music to Affect the Behavior of Supermarket Shoppers ", Journal of Marketing, 46,3, 86-91.

Mitchell, Khan et Knasko (1995), "There's Something in the Air : Effects of Congruent or Incongruent Ambient Odor on Consumer Decision Making ", Journal of consumer Research, 22, 229-237.

Quartier, Christiaans, and Van Cleempoel (2009). "Retail design: lighting as an atmospheric tool, creating experiences which influence consumers' mood and behaviour in commercial spaces ". Undisciplined! Design Research Society Conference 2008, Sheffield Hallam University, Sheffield, UK, 16-19 July 2008.

Radeloff (1990), "Role of color in Perception of Attractiveness ", Perception and Motor Skills, vol. 71, 151-160.

Rieunier (2004), "Le marketing sensoriel chez Nature \& Découvertes : faire évoluer l'offre sensorielle sur 10 ans sous contraintes du consommateur. Interview de Françoise Vernet, directrice marketing de Nature \& Découvertes ", Décisions Marketing, $n^{\circ} 33,77$ 80.

Spangenberg Et Crowley, (1996), " Améliorer l'environnement du magasin: les signaux olfactifs affectent-ils les évaluations et les comportements?", RAM, n¹1.

Summers \& Hebert (2001), "Shedding some Light on Store Atmospherics : Influence of Illumination on Consumer Behavior ", Journal of Buisness Reseach, vol. 54, n² 2, 145-150.

Zelner et Kautz (1990), "Color Affects Perceived Odor Intensity “, Journal of Experimental Psychology: Human Perception \& Performance, vol. 16, n², 391-397. 